\title{
A Novel MK-based Geopolymer Composite Activated with Rice Husk Ash and KOH: Performance at High Temperature
}

\author{
M.A. Villaquirán-Caicedo ${ }^{\mathrm{a}} \bowtie$, R. Mejía de Gutiérrez ${ }^{\mathrm{a}}$, N.C. Gallego ${ }^{\mathrm{b}}$ \\ a. Composite Materials Group, (CENM) School of Materials Engineering, University of Valle, (Cali. Colombia) \\ b. Carbon \& Composites Group, Materials Science \& Technology Division Oak Ridge National Laboratory \\ (Oak Ridge, United States) \\ $\triangle$ monica.villaquiran@correounivalle.edu.co
}

\author{
Received 17 February 2016 \\ Accepted 29 August 2016 \\ Available on line 6 February 2017
}

\begin{abstract}
Geopolymers were produced using an environmentally friendly alkali activator (based on Rice Husk Ash and potassium hydroxide). Aluminosilicates particles, carbon and ceramic fibres were used as reinforcement materials. The effects of reinforcement materials on the flexural strength, linear-shrinkage, thermophysical properties and microstructure of the geopolymers at room and high temperature $\left(1200^{\circ} \mathrm{C}\right)$ were studied. The results indicated that the toughness of the composites is increased $110.4 \%$ for geopolymer reinforced by ceramic fibres (G-AF) at room temperature. The presence of particles improved the flexural behaviour $265 \%$ for geopolymer reinforced by carbon fibres and particles after exposure to $1200{ }^{\circ} \mathrm{C}$. Linear-shrinkage for geopolymer reinforced by ceramic fibres and particles and the geopolymer G-AF compared with reference sample (without fibres and particles) is improved by $27.88 \%$ and $7.88 \%$ respectively at $900{ }^{\circ} \mathrm{C}$. The geopolymer materials developed in this work are porous materials with low thermal conductivity and good mechanical properties with potential thermal insulation applications for building applications.
\end{abstract}

KEYWORDS: Composite; Metakaolin; Alkali-activated cement; Mechanical properties; Thermal analysis

Citation/Citar como: Villaquirán-Caicedo, M.A.; Mejía de Gutiérrez, R.; Gallego, N.C. (2017) A Novel MK-based Geopolymer Composite Activated with Rice Husk Ash and KOH: Performance at High Temperature. Mater. Construcc. 67 [326], e117. http://dx.doi.org/10.3989/mc.2017.02316.

RESUMEN: Nuevo material compuesto de matriz geopolimérica activado con ceniza de cascarilla de arroz y KOH: Desempeño a alta temperatura. Compuestos geopoliméricos fueron producidos usando un activador alcalino alternativo (basado en ceniza de cascarilla de arroz e hidróxido de potasio), partículas aluminosilicatos, fibras de carbono y cerámicas. Se estudió el efecto de fibras y partículas en la resistencia a la flexión, contracción lineal, propiedades termofísicas y microestructura de los geopolímeros a temperatura ambiente y $1200{ }^{\circ} \mathrm{C}$. Los resultados indican que la tenacidad se incrementó $110.4 \%$ para el geopolímero reforzado con fibras cerámicas (G-AF) a temperatura ambiente. La presencia de partículas mejora el comportamiento a la flexión $265 \%$ para el geopolímero reforzado con fibras de carbono y partículas después de la exposición a $1200{ }^{\circ} \mathrm{C}$. La contracción lineal para el geopolímero reforzado con fibras cerámicas y partículas y el geopolímero G-AF es mejorada $27.88 \%$ y $7.88 \%$ respectivamente a $900{ }^{\circ} \mathrm{C}$ con respecto al material sin refuerzo. Los materiales geopoliméricos desarrollados en este estudio son materiales porosos de baja conductividad térmica y buenas propiedades mecánicas con potencial aplicación en la industria de la construcción como aislantes térmicos.

PALABRAS CLAVES: Compuesto; Metacaolín; Cemento de activación alcalina; Propiedades mecánicas; Análisis térmico

ORCID ID: M. A. Villaquirán-Caicedo (http://orcid.org/0000-0001-5145-0472); R. Mejía de Gutiérrez (http://orcid. org/0000-0002-5404-2738); N. C. Gallego (http://orcid.org/0000-0002-8252-0194)

Copyright: (C) 2017 CSIC. This is an open-access article distributed under the terms of the Creative Commons Attribution License (CC BY) Spain 3.0. 


\section{INTRODUCTION}

Geopolymers are amorphous materials synthesized by the alkaline activation of a wide variety of aluminosilicate minerals, including metakaolin (MK), and industrial by-products such as fly ash, blast furnace slag, waste glasses, and others (1-6). The utilization of alkaline activators based on alternative sources of $\mathrm{SiO}_{2}$ (waste or industrial byproducts) for the synthesis of geopolymers is of significant interest because it has the potential to lead greater environmental sustainability. The production of commercial silicate solutions $\left(\mathrm{Na}_{2} \mathrm{SiO}_{3} \cdot \mathrm{nH}_{2} \mathrm{O}\right.$ and $\mathrm{K}_{2} \mathrm{SiO}_{3} \cdot \mathrm{nH}_{2} \mathrm{O}$ ) involves a high energy demand (temperatures close to $1000{ }^{\circ} \mathrm{C}-1400{ }^{\circ} \mathrm{C}$ ) and the emission of greenhouse gases $(7,8)$. In recent years there has been great interest for the use of alternative sources of amorphous reactive silica for producing alkaline activators: rice husk ash (3, 4, 9-17), silica fume $(2,3,18-21)$ and waste glasses $(1,22-25)$ have been used and have shown similar microstructure and mechanical performance to geopolymers produced with commercial soluble silicate solutions $(3,9,18,26,27)$.

Rice husk is the hard coating of the rice grain, and is composed of minerals that need to be removed for human consumption. Between $20-25 \%$ of Paddy rice is an indigestible shell, this product is generally used as a fuel in a boiler for plant electricity generation or as a fertilizer for agriculture. The combustion of this shell generates $\sim 18 \%$ volume of ash, however, the production of 1 ton of rice result in about $45 \mathrm{~kg}$ (RHA), depending on the rice variety, climate, type of furnace and burning temperature. Chemical composition and crystalline content of the RHA varies depending of processing conditions (28). The RHA is composed largely of silica $\left(87-97 \mathrm{wt}^{\mathrm{O}} \%\right.$ ) with small amounts of inorganic salts, making this a sustainable source of Si for various applications (29-31). Rice worldwide production was estimated at 20 Mt by 2013 (32) and globally the leading producers of rice are Chinese (7.2 Mt), India (5.5 Mt), Indonesia $(2.2 \mathrm{Mt})$ and Bangladesh $(1.7 \mathrm{Mt})$. According to the USA Rice Federation in rice production it is estimated to exceed $\sim 20$ billion Ton annually, that gives an approximately $0.35 \mathrm{Mt}$ of RHA (33). Locally, in Colombia for the first half of 2015 the production of Paddy rice was 780997 Ton, of which it is estimated that the amount of rice husk was $\sim 195250$ ton and therefore $\sim 35144$ ton RHA (34). With this is possible estimate that in 2015 there were approximately $\sim 70000$ ton of RHA, amount considerable for final disposal.

Geopolymers exhibit brittle behaviour under flexural loads, affecting their potential use for extensive engineering applications. By bridging cracks, a wide range of polymeric, mineral and natural fibres have been used to improve geopolymer tensile and flexural strength, toughness, and energy absorption capacities (35). Short fibres of polypropylene (PP) $(36,37)$, polyvinyl alcohol (PVA) (38), basalt $(39,40)$, glass $(41,42)$, carbon $(43,44)$, alumina $(45,46)$ and steel $(47)$ have been successfully incorporated into geopolymers at volume fractions between $0.5-3.5 \%$. Higher fibre contents, up to $20 \%$ (44), provide more control over cracking and increase mechanical strength of the brittle matrix.

Geopolymer composite materials reinforced with ceramic particles have also been assessed, and the inclusion of alumina, nanosilica, zirconia $(49,50)$, quartz, granular inorganic fillers from demolition waste materials, and crushed refractory particles (45), increase geopolymer mechanical performance, especially under compressive loads (45, $51,52)$. The inclusion of mineral reinforcements can also provide positive effects when the material is exposed to high temperatures, such as the retention of mechanical properties and cracking reduction. Although MK-based geopolymers can exhibit structural stability at temperatures higher than $1000{ }^{\circ} \mathrm{C}$, some reports show a remarkable loss of mechanical strength at temperatures below $300{ }^{\circ} \mathrm{C}$ as a consequence of the dehydration and dehydroxylation processes of the reaction products (53). The inclusion of fibres can curb this thermal shrinkage at temperatures between $200{ }^{\circ} \mathrm{C}$ and $500{ }^{\circ} \mathrm{C}$, reducing the loss of mechanical strength and improving thermal stability $(45,48)$. The inclusion of carbon fibres in geopolymers that have been exposed to $1400{ }^{\circ} \mathrm{C}$ under controlled atmosphere has been shown to lead to the formation of $\beta$-SiC, indicating that the $\mathrm{C}$ from the fibres can react with $\mathrm{Si}-\mathrm{O}$ units from the reaction products (48). The structural densification and subsequent formation of leucite-type structures in MK-based geopolymers activated with $\mathrm{K}$-silicate and then exposed to temperatures higher than $900{ }^{\circ} \mathrm{C}$ can promote the development of advanced ceramics that exhibit considerably high flexural strength $(>100 \mathrm{MPa})(54)$.

This paper presents the assessment of MK-based composite geopolymers produced using an environmentally friendly alkali activator and two different types of fibres, carbon fibre and alumina fibre, which were introduced to reduce cracking. Refractory particles were also added to the geopolymers for the improvement of volumetric contraction and the study of mechanical performance. The effectiveness of these reinforcements was assessed by the examination of flexural strength loss resulting from exposure to temperatures up to $1200{ }^{\circ} \mathrm{C}$. Effects of the high temperature on microstructure were studied using Scanning Electron Microscopy (SEM), and X-Ray Diffraction (XRD). Additionally, physical and thermal properties were evaluated. 


\section{MATERIAL AND METHODS}

\subsection{Materials}

A commercial metakaolin (MK) MetaMax ${ }^{\circledR}$, supplied by BASF, was used as an aluminosilicate precursor. The MK exhibited a particle size distribution between 1 and $40 \mu \mathrm{m}$, with a mean particle size of $7.8 \mu \mathrm{m}$. A potassium silicate solution, derived from the dissolution of analytical potassium hydroxide pellets $(\mathrm{KOH})$ along with rice husk ash (RHA), was used as an alkaline activator. RHA with $92 \%$ amorphous $\mathrm{SiO}_{2}$ content was obtained by controlled calcination of rice husk at $600{ }^{\circ} \mathrm{C}$ for two hours, followed by ball milling for 30 minutes, resulting in an average particle size of $22.84 \mu \mathrm{m}$. The proportions of RHA and $\mathrm{KOH}$ were adjusted to produce alkali activator solutions with a $\mathrm{K}_{2} \mathrm{O} / \mathrm{SiO}_{2}$ molar ratio of 0.28 . The commercial potassium silicate $\left(\mathrm{K}_{2} \mathrm{O} \cdot \mathrm{SiO}_{2} \cdot \mathrm{H}_{2} \mathrm{O}\right)$ used as an alkaline activator (for comparison) was supplied by Productos Químicos Panamericanos ${ }^{\circledR}$, the mass composition is $\mathrm{K}_{2} \mathrm{O}=13.06 \%, \mathrm{SiO}_{2}=26.38 \%$ and $\mathrm{H}_{2} \mathrm{O}=60.56 \%$.

To increase the mechanical performance of the material, aluminosilicate refractory particles (RP) with a mean size of $81.95 \mu \mathrm{m}$ were used for reinforcement. These particles were obtained from a KT33 brick (supplied by REFRASTRABE S.A.) using jaw crusher milling followed by ball milling. The fibrous reinforcement was carried out using the two fibres types described below:

-Carbon fibres (CF): Panex $35^{\circledR}$, supplied by ZOLTEK, had an absolute density of $1810 \mathrm{~kg} / \mathrm{m}^{3}$, an average diameter of approximately $9 \mu \mathrm{m}$, and a length of approximately $100 \mu \mathrm{m}$.

-Alumina fibres (AF): Alumina-silica-zirconia fibres, denoted as CERACHEM ${ }^{\circledR}$, were supplied by Thermal Ceramics and had an average diameter of $2.18 \mu \mathrm{m}$. Chemical compositions and some physical properties of the raw materials used are listed in Table 1.

\subsection{Sample preparation}

Geopolymers were synthetized by adjusting the quantities of the precursor ( $\mathrm{MK}$ ) and the alkali activator to obtain overall $\mathrm{SiO}_{2} / \mathrm{Al}_{2} \mathrm{O}_{3}$ and $\mathrm{K}_{2} \mathrm{O}$ / $\mathrm{SiO}_{2}$ molar ratios of 2.5 and 0.28 , respectively. A water-to-solid ratio of 0.4 was used for geopolymer matrix and 0.44 for composite geopolymer, the higher water-to-solid ratio for composites geopolymer was to achieve the same workability. The alkali activators were prepared $20 \mathrm{~h}$ prior to usage (by mixing RHA, $\mathrm{KOH}$ pellets and water) were stored in sealed plastic containers with magnetic stirring to achieve the completely dissolution of RHA. For comparison purposes, commercial potassium silicate was used like alkali activator for preparation of reference paste (KS). The concentration of $\mathrm{KOH}$ solution was $8 \mathrm{M}$.

The geopolymers matrix were obtained by mixing of alkali activator with MK using a HOBART mixer for $7 \mathrm{~min}$ to achieve adequate fluidity of paste. After mixing, the fresh paste was cast into plastic moulds and vibrated to release any residual air bubbles. Subsequently, the moulded samples were sealed with plastic film to minimize loss of evaporable water and then transferred into sealed containers.

Composites geopolymer were prepared following the procedure: (i) For the fibre-composites, fibres were pre-mixed for five minutes with alkali-solution before being added to the MK, composite geopolymers were produced using 3 vol.\% of fibre mixture. (ii) For fibre-RP composites, refractory particles (20 vol. \%) were added to the blend (activator, fibres and MK), after five min of mixing RP was added and continue the mixing for other two min to achieve adequate homogeneity before being cast.

TABLE 1. Chemical composition and physical properties of raw materials used

\begin{tabular}{|c|c|c|c|c|c|}
\hline & & MK & RHA & RP & $\mathbf{A F}$ \\
\hline \multirow{9}{*}{$\begin{array}{l}\text { Chemical composition } \\
\text { (wt \%) }\end{array}$} & $\mathrm{SiO}_{2}$ & 51.52 & 92.33 & 57.99 & 50.00 \\
\hline & $\mathrm{Al}_{2} \mathrm{O}_{3}$ & 44.53 & 0.18 & 36.62 & 34.90 \\
\hline & $\mathrm{TiO}_{2}$ & 1.71 & -- & 2.03 & 0.04 \\
\hline & $\mathrm{Fe}_{2} \mathrm{O}_{3}$ & 0.48 & 0.17 & 1.52 & 0.05 \\
\hline & $\mathrm{Na}_{2} \mathrm{O}$ & 0.29 & 0.07 & -- & -- \\
\hline & $\mathrm{K}_{2} \mathrm{O}$ & 0.16 & 0.15 & -- & -- \\
\hline & $\mathrm{MgO}$ & 0.19 & 0.49 & 0.51 & 0.07 \\
\hline & $\mathrm{CaO}$ & 0.02 & 0.63 & 1.32 & 0.08 \\
\hline & L.O.I. $\left(950^{\circ} \mathrm{C}\right)$ & 1.09 & 2.57 & -- & -- \\
\hline \multirow[t]{2}{*}{ Physical Properties } & Density $\left(\mathrm{kg} / \mathrm{m}^{3}\right)$ & 2500 & 2140 & 2863 & 2650 \\
\hline & BET Specific surface $\left(\mathrm{m}^{2} / \mathrm{kg}\right)$ & 12.7 & 78.28 & -- & -- \\
\hline
\end{tabular}

L.O.I.: Loss on ignition. 
All the samples were cured in sealed containers at $70{ }^{\circ} \mathrm{C}$ for $20 \mathrm{~h}$ and $90 \% \mathrm{RH}$. At the end of the curing time, the specimens were removed from their moulds and stored in sealed containers at room temperature $\left(\sim 25^{\circ} \mathrm{C}\right)$ until mechanical testing and microstructural characterization.

Nine samples were prepared for each study (3 unexposed, 3 exposed to $600{ }^{\circ} \mathrm{C}$ and 3 exposed to $1200^{\circ} \mathrm{C}$ ). A summary of the different geopolymer composites is listed in Table 2.

\subsection{Elevated temperature exposure}

After 7 days of curing, the samples were dried for eight days at room temperature and for eight more days at $60{ }^{\circ} \mathrm{C}$, with the aim that the adsorbed water was released slowly without generating thermal contractions that then will cause cracking before exposure at high temperature. To perform flexural strength tests on specimens exposed to elevated temperatures, the specimens were first heated at a rate of $1{ }^{\circ} \mathrm{C}$ per minute to the target temperature in an electrical furnace. Once the predetermined target temperature was reached, specimens were kept at the target temperature for $120 \mathrm{~min}$ to attain thermal stability. Then, the furnace heat was turned off, and the specimens were allowed to cool naturally. After cooling to ambient temperature, the specimens were taken out of the furnace, and flexural strength tests were conducted.

\subsection{Tests conducted}

The bulk density, percent absorption, and percent voids in geopolymer samples were determined following the procedure described by the standard ASTM C642-13.

Linear shrinkage measurements were performed on a Netzch DIL 402 PC horizontal pushrod dilatometer. Measurements were taken between $25^{\circ} \mathrm{C}-1000{ }^{\circ} \mathrm{C}$, using cylindrical samples with a $4.6 \mathrm{~mm}$ diameter and a $25 \mathrm{~mm}$ length at a constant heating rate of $10{ }^{\circ} \mathrm{C} / \mathrm{min}$ and a constant load of $30 \times 10^{-2} \mathrm{~N}$. Sapphire was used as a reference pattern.

Flexural strength was measured using a threepoint bend test following ASTM C1341-13 for prismatic samples of dimensions $30 \times 10 \times 180 \mathrm{~mm}$ (55). The tests were performed using an INSTRON universal testing machine with a cross-head speed of $0.43 \mathrm{~mm} / \mathrm{min}$; a $160 \mathrm{~mm}$ support span was used for unexposed samples and a $100.5 \mathrm{~mm}$ support span was used for samples exposed to $1200^{\circ} \mathrm{C}$. In this paper, the fracture work of samples was calculated as the area of the load-displacement (P-d) curve up to deflection corresponding to maximum load. Volumetric contraction was determined directly by measuring sample dimensions (length and diameter) with callipers and calculating the volume, assuming that the sample remained

The thermal diffusivity of the samples was measured according to ASTM E1461-07, using the laser flash technique with an Anter Flashline 4010 system. Samples of each composition were tested in an argon atmosphere $(\sim 55 \mathrm{~Pa})$ at room temperature. The specimens were prepared such that they were homogeneous without fissures and holes. The surface was coated with a graphite powder spray so as to avoid any reflectance. Three shots were taken for each sample at each temperature with a 1300 Wlaser, and the diffusivity was calculated by utilizing the Clark and Taylor correction method (56). Molybdenum standard was analyzed with each sample to allow for the calculation of specific heat capacity and thermal conductivity. The thermal conductivity $\kappa$ was then calculated according to Eq. [1].

$$
K=\alpha C p \rho
$$

Here $\alpha$ is the thermal diffusivity, $\mathrm{Cp}$ is the specific heat capacity at constant pressure and $\rho$ is the density.

Fracture surfaces of the composites tested for flexural strength were observed by scanning electron microscopy (SEM), performed using a JEOL JSM-6490LV and $20 \mathrm{kV}$ of accelerating voltage. The samples were coated with Au and observed in a low vacuum mode.

X-ray diffraction (XRD) data were collected on an X'Pert MRD PANalytical diffractometer with

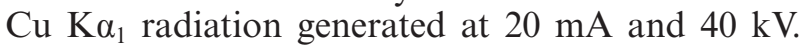
Typical specimens were step scanned from $8^{\circ}$ to $60^{\circ}$ $2 \theta$ at $0.02^{\circ} 2 \theta$ steps, integrated at the rate of $4.0 \mathrm{~s}$ per step.

TABLE 2. Compositions of the synthesized geopolymer composites

\begin{tabular}{lcccc}
\hline Geopolymer composite ID & Type of Fibre & Fibre volume, $\%$ & Particles volume, $\%$ & Silica source \\
\hline KS & 0 & 0 & 0 & Potassium silicate \\
G & 0 & 0 & 0 & RHA \\
G-CF & Carbon & 3 & 0 & RHA \\
G-AF & Alumina & 3 & 0 & RHA \\
G-CF/RP & Carbon & 3 & 20 & RHA \\
G-AF/RP & Alumina & 3 & 20 & RHA \\
\hline
\end{tabular}




\section{RESULTS AND DISCUSSION}

\subsection{Physical and mechanical properties}

A summary of density and open porosity for the different geopolymers is presented in Table 3. The densities for $\mathrm{KS}$ and $\mathrm{G}$ matrix are similar regardless of the silica source used. Comparing the different silica sources ( $\mathrm{G}$ and $\mathrm{KS}$ ) the open porosity was found to be higher in $G$, this is due to the higher hydration energy associated with the smaller particles of RHA $(9,57)$.

The bulk densities in G, G-AF and G-CF are similar regardless of the fibre used. The open porosity of the geopolymers with fibers is significantly higher than the open porosity of the geopolymer without fibers (G and KS). This is expected since the composites samples contain higher amounts of water compared to the $\mathrm{G}$ matrix. Comparing the geopolymers G-AFRP with the reference sample based on RHA (G), the open porosity was found to be lower for G-AFRP due to the presence of RP reduces the porosity of the sample. G-CFRP is less dense than $\mathrm{G}$, there are controversial results in the bulk density, because this material must be the material with higher density due to presence of $\mathrm{BS}$ and the result was not expected.

TABLE 3. Density and open porosity in geopolymers

\begin{tabular}{lcc}
\hline Material & \% Open porosity & Bulk density $\left(\mathbf{k g} / \mathbf{m}^{\mathbf{3}}\right)$ \\
\hline KS & 33.4 & 1740 \\
G & 35.5 & 1690 \\
G-AF & 38.4 & 1620 \\
G-CF & 37.7 & 1700 \\
G-AFRP & 30.2 & 1790 \\
G-CFRP & 35.4 & 1450 \\
\hline
\end{tabular}

The load-displacement curves for the geopolymer composites are given in Figure 1 for geopolymers exposed at $25^{\circ} \mathrm{C}$ and at $1200^{\circ} \mathrm{C}$. At room temperature, comparing the flexural performance for matrix with different silica sources, it can be seen that the RHA-based matrix shows similar behaviour that matrix based on commercial potassium silicate. $G$ matrix supports slightly greater load values before the fault than KS matrix. The geopolymer matrix ( $\mathrm{G}$ and $\mathrm{KS}$ ) and geopolymer composite reinforced with carbon fibres (G-CF) show catastrophic fracture behaviour at $25^{\circ} \mathrm{C}$ (Figure 1a). G-AF samples, on the other hand, demonstrate non-catastrophic fracture behaviour with elastic composite extension observed at the beginning of the test (51). It is known that fibres in cementitious materials provide control over cracking and increase fracture toughness of the brittle matrix through bridging action that occurs during both micro- and macro- cracking of the matrix $(36,47)$. Fibres have also been observed to reduce the propagation of micro-cracks when the material is under a load.

The results showed that geopolymer composites with alumina fibres can withstand higher loads than those with carbon fibres can. This difference could be attributed to better bonds and possibly higher interactions between the alumina fibres and the geopolymer matrix, both due to similar chemical composition.

The toughness and the loading capacity of composite materials at $25^{\circ} \mathrm{C}$ increased due to the use of both fibres and particles. These results were attributed to the modified post-cracking performance of the composites (Figure 1). G-CFRP and G-AFRP samples initially showed brittle fracture up to a certain load, followed by a "plastic" deformation or ductile failure associated with the contribution of fibre bridging to the conservation of material integrity. However, the particles included in G-AFRP
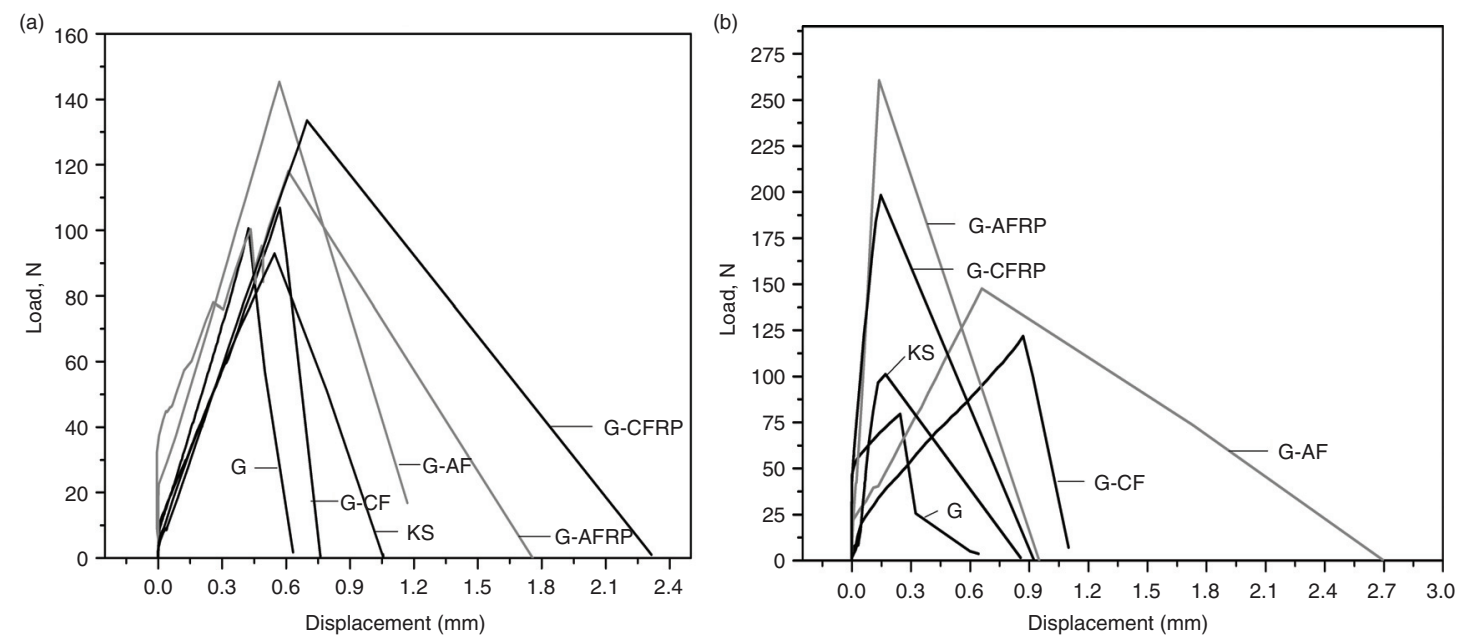

Figure 1. P-d curves for geopolymers composites (a) at room temperature and (b) after exposition at $1200^{\circ} \mathrm{C}$. 
reduced the maximum loading capacity of the composite compared with G-AF. The toughness was substantially similar to G-AF, and the composite material presented a more ductile type of fracture. In G-CFRP, the inclusion of particles modified the flexural loading of the composite to higher values. Additionally, enhanced toughness was indicated by the deflection at which fracture occurs being higher than that reported for $\mathrm{G}-\mathrm{CF}$.

The effect of exposure to $1200{ }^{\circ} \mathrm{C}$ was different for the fibre-reinforced samples compared to the samples that were reinforced with both fibres and particles. It has been reported that the tensile strength of carbon fibres decreased with increasing temperature and that after exposure to $500{ }^{\circ} \mathrm{C}$, carbon fibres only retained $25 \%$ of their ambient temperature strength (58). Thus, the addition of $\mathrm{CF}$ had almost no influence on the flexural strength of geopolymers after exposure to $500{ }^{\circ} \mathrm{C}$ (54), similar similar behavior was found by Masi et al. (59) using PVA fibres and by $\mathrm{He}$ et al. (58). When compared with unreinforced matrix, G-CF and G-AF samples showed increased fracture work associated with higher loading capacities and steeper slopes. In the case of materials reinforced with ceramic fibers (G-AF), although the fibers have melting point of $1760^{\circ} \mathrm{C}$, these fibers being in contact with the alkaline medium react and loss of integrity occurs, creating a porous matrix as can be seen in the SEM images; Masi et al. (59) found similar behavior for basalt fiber reinforced materials. Fibre- and fibreparticle-reinforced composites exhibited somewhat "plastic" type fractures. However, those fractures did not show fibres. Similar deflection values were exhibited by all samples assessed. Alumina fibre composites, G-AF and G-AFRP, showed pronounced increases in loading capacity. For G-AFRP and G-CFRP, this suggested that the incorporation of high particle content $(20 \%)$ modified the ductility of the material even at high temperature and contributed to the strengthening of the matrix by increasing obstruction of crack propagation paths.

Furthermore, in this case, the carbon fibres likely acted as particles due to their short length of 100 microns. This suggests that the incorporation of low fibre volume $(3 \%)$ did not modify the ductility of the material but rather contributed to the strengthening of the matrix as a consequence of the obstruction of crack propagation paths. Figure 2 shows the values for modulus of rupture (MOR) were calculated based on the flexural curves. Before exposure to high temperatures, the incorporation of fibres did not significantly increase the MOR of the geopolymer matrix because the fibre volume was not sufficient to increase the strength. However, the addition of fibres was important because the fracture work was increased by the bridging of fibres, and the ductility of the composite was improved compared to that of the geopolymer matrix (Table 4). At room

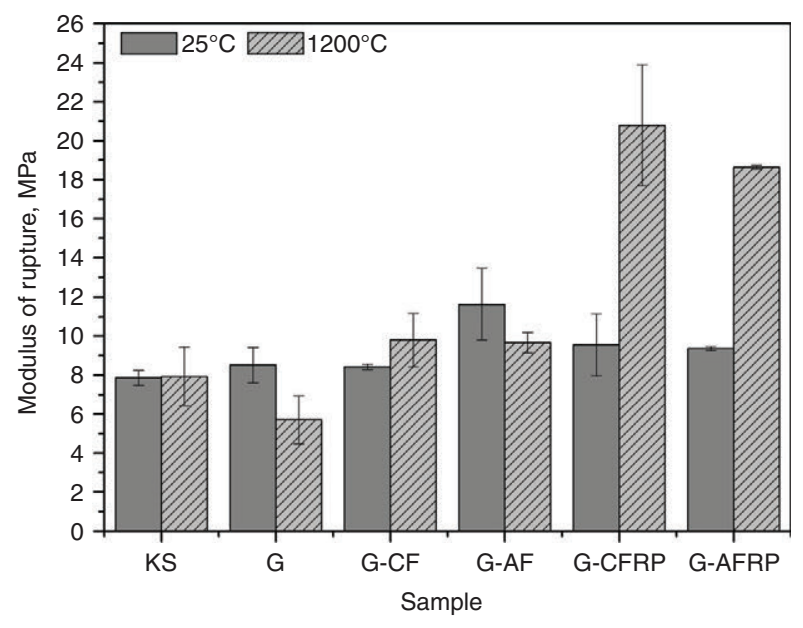

FIgURE 2. Modulus of rupture for geopolymer composites before and after heat treatment at $1200^{\circ} \mathrm{C}$.

TABLE 4. Fracture Work of geopolymer composites at different heat treatment temperatures

\begin{tabular}{lcc}
\hline & \multicolumn{2}{c}{ Fracture Work, (J.mm) } \\
\cline { 2 - 3 } Sample & $\mathbf{2 5}^{\circ} \mathbf{C}$ & $\mathbf{1 2 0 0}^{\circ} \mathbf{C}$ \\
\hline KS & 28.23 & 9.63 \\
G & 22.14 & 16.28 \\
G-CF & 27.76 & 53.34 \\
G-AF & 46.63 & 59.66 \\
G-CFRP & 49.81 & 47.13 \\
G-AFRP & 47.73 & 7.089 \\
\hline
\end{tabular}

temperature, the MOR decreased by $1.10 \%$ for G-CF compared to non-reinforced matrix $(\mathrm{G})$. The addition of carbon fibres and refractory particles into the geopolymer matrix (G-CFRP) increased the MOR by $12.14 \%$. Furthermore, the addition of AF into the matrix increased the MOR by $36.43 \%$ and $9.93 \%$ for G-AF and G-AFRP, respectively. These results were much better than the results shown by Bernal et al. (45); in this paper, the MOR value for sample $\mathrm{G}$ is $77 \%$ higher than that of the matrix tested in that investigation. The MOR value for G-CF was similar to the MOR shown by Zhang et al. (60) for samples with $1 \%$ of CF. The samples tested at $600{ }^{\circ} \mathrm{C}$ showed MOR values below $1 \mathrm{MPa}$. Similar behaviour for samples with carbon fibres were also shown by Zhang et al. (60).

The results of MOR for fibre-reinforced composites (G-CF and G-AF) indicated that the inclusion of $3 \%$ volume had a noticeable effect on strength after exposure to elevated temperature fibre. Zhang et al. (60) found that for geopolymer with addition of $2 \%$ milled carbon fibre this volume to provide effective control of cracking to $500{ }^{\circ} \mathrm{C}$ and the fibers do not significantly influence the resistance at high temperature $\left(700{ }^{\circ} \mathrm{C}\right)$. However, flexural strength 
was improved by the Addition of RP, which effectively reduced the linear shrinkage and maintained stability at high temperatures composite. The MR values are similar to the results that are known to pastes OPC $(61,62)$ and OPC fibro reinforced $14 \mathrm{MPa}$ (63). These results are similar to the results presented by Luna-Galiano for geopolymer based on fly ash (62). In addition, in the current study it highlights that the results are higher than those obtained by Martauz (64) using hybrid cement composed of fly ash, granulated blast furnace slag and the highly alkaline waste from red mud. Latella (65) using as raw material MK and different alkaline activators based on sodium silicate and $\mathrm{NaOH}+$ silica fume; It emphasizes that in this study the geopolymer pastes $\mathrm{G}$ and KS showed higher strength than those presented by Latella (2008) for geopolymers compounds with $40 \%$ sand bending: sodium silicate (7.2 MPa) and $\mathrm{NaOH}+$ silica fume (7.4 MPa). Also for RHA-based samples Haeng (14) reported values of flexural strength at room temperature of 7.21 $\mathrm{MPa}$, in this research the results are slightly above these values reported.

At $1200{ }^{\circ} \mathrm{C}$, the MOR of the matrix was reduced, and the values obtained are similar to values reported by Zuda et al. (64). For G-CF and G-AF composites, the MOR values increased by $72.2 \%$ and $69.7 \%$, respectively. Samples reinforced with both fibre and RP showed MOR improvements of approximately $265.1 \%$ and $227.1 \%$ for G-CFRP and G-AFRP, respectively. It is important to highlight that the MOR values achieved in this research are higher than those achieved during other studies (41). This is may be because the geopolymer is sintered at $1200{ }^{\circ} \mathrm{C}$, porosity is reduced, crystalline phases such as leucite and mullite are formed, and the particles obstruct the advance of the cracks, aiding in the compaction of the material. This obstruction is due to a favourable interaction between the particles and the geopolymer matrix. The addition of RP and different types of fibres, such as carbon or ceramic fibre, into the geopolymer matrix did not improve the MOR of composites at room temperature, but in composites subjected to high temperatures, the MOR was improved to a certain extent. The addition of both RP and fibres effectively keeps the composites stable at high temperatures. The alumina fibres reacted with the geopolymer at high temperature $\left(>1000{ }^{\circ} \mathrm{C}\right)$, and below this temperature, the fibres maintained the integrity of the composite during heating.

The RP did not react with the matrix, and the composite material effectively acted as a largeparticle composite. These particles reinforced by restraining the movement of geopolymer matrix in the vicinity of each particle; in essence, the matrix transferred some of the applied stress to the particles (59), which bear a fraction of the load. MOR results (Figure 2) emphasized that the degree of reinforcement, or improvement of mechanical behaviour, depended on strong bonding at the matrix-particle interface.

Figure 3 illustrates the linear composition analysis using Energy-dispersive X-Ray spectroscopy (EDS) at the matrix-particle interface in G-RP at $25^{\circ} \mathrm{C}$ and after exposure at $1200{ }^{\circ} \mathrm{C}$. This line indicated that there was no reaction between the particles and the geopolymer matrix at any temperature. The EDS line scans show the composition of each component of the system; there were no visible transition zones where a chemical reaction might have occurred.

The physical appearances of the specimens heated to $1200{ }^{\circ} \mathrm{C}$ are presented in Figure 4. MK-based geopolymers without fibre $(G)$ developed serious cracks and were highly prone to rupture even under smaller loads. However, no noticeable cracks developed in the reinforced composites. This clearly demonstrated that fibres and particles provided effective crack control mechanisms for geopolymers under high temperature. The physical appearances of the composite geopolymers heated to $1200{ }^{\circ} \mathrm{C}$ showed decent prevention of cracks during heating; stability of reinforced composites was achieved when exposed to temperatures up to $1200^{\circ} \mathrm{C}$.

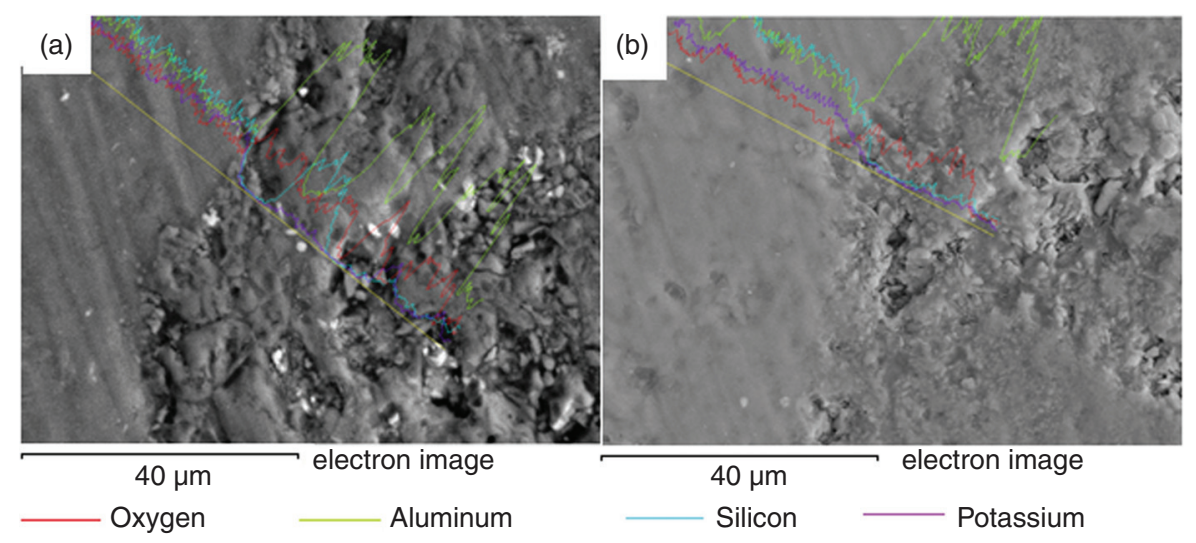

FIgURE 3. SEM line scanning images for composites with RP (a) to $25^{\circ} \mathrm{C}$ and (b) to $1200{ }^{\circ} \mathrm{C}$. 


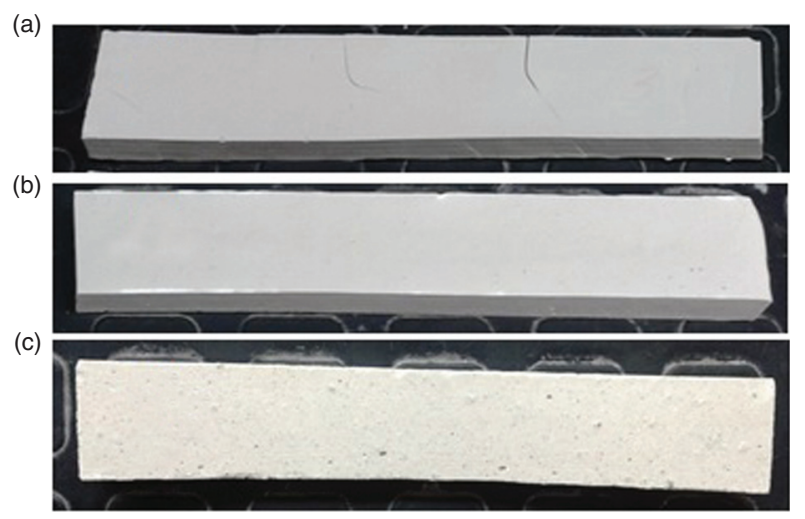

Figure 4. Appearance of the MK-based geopolymer composites after exposure to $1200^{\circ} \mathrm{C}$ for $2 \mathrm{~h}$ : (a) $\mathrm{G}$, (b) G-CF and (c) G-AFRP.

\subsection{Thermophysical properties}

Dilatometer curves of the G, G-AF and G-AFRP geopolymers are shown in Figure 5. Dilatometer tests were chosen for composites samples with AF because had the lowest density. An onset of initial and rapid shrinkage occurs in region I. A high strain, between 2.2 to $3.2 \%$ shrinkage occurred for all samples up to $300{ }^{\circ} \mathrm{C}$ due to the capillary contraction created when free or weakly bound water evaporated from the micro- and nano-pores of the geopolymer $(9,48)$. Consequently, pore solution is released from the gel causing the microstructure and nanostructure of the gel to rearrange (region II). Thermal stability or low shrinkage can be observed in region III for all geopolymers, this behavior coincides with other studies conducted. Duxson et al. (53) and Rickard (67) have reported a minimal rate of shrinkage in this region, mostly attributed to physical contraction due to slow dehydroxylation of bound hydroxyls. According to Duxson et al. (53) at this stage, complete dehydroxylation in specimens occurred, limited by physical arrangement and dislocation of the hydroxyl groups and their reactivity. The distribution of silanol and aluminol groups on the surface of the gel is due to the reaction of two hydroxyl groups, which together formed an aluminosilicate network. Small thermal shrinkage can be observed due to physical contraction of the gel, caused by the formation of tetrahedral $\mathrm{Si}$ and Al linkages (68). The densification of geopolymers occurs in the region IV $\left(\sim 820-950{ }^{\circ} \mathrm{C}\right)$. Onset temperatures decrease slightly or sharply appear due to softening and viscous sintering $(9,58,69,70)$. The physical evolution of geopolymer materials during heating is a critical factor in determining their suitability for applications including construction and refractory materials (69). Additionally, since the region $\mathrm{I}$, it was possible to observe that the shrinkage for G-AF and G-AFRP geopolymers were controlled using fibres and particles. At $300^{\circ} \mathrm{C}$, the linear

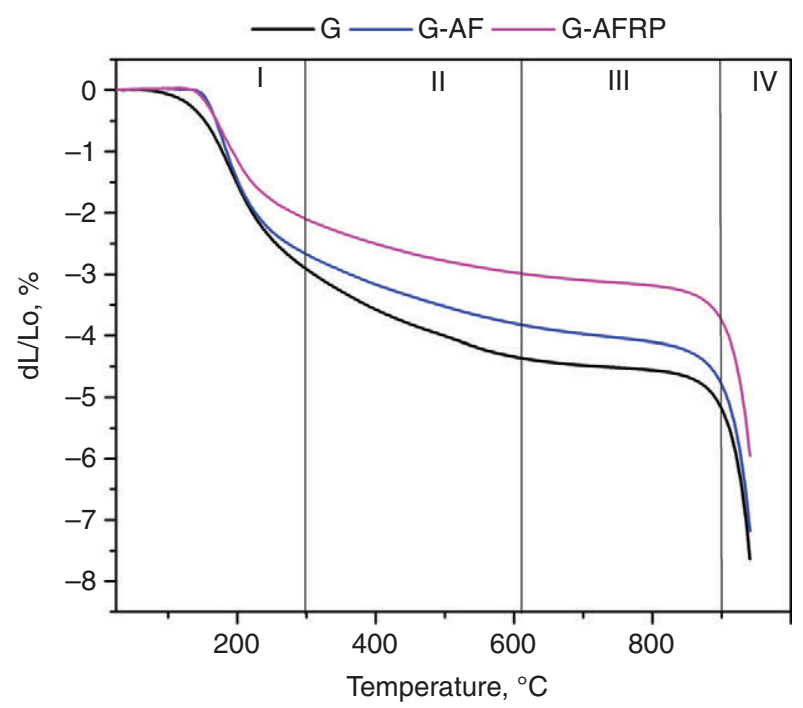

FIGURE 5. Linear shrinkage of the geopolymer samples (bulk samples were cured in sealed plastic tubes at $72{ }^{\circ} \mathrm{C}$ for $20 \mathrm{~h}$ ).

shrinkage was reduced compared to the $\mathrm{G}$ matrix by approximately $8.24 \%$ and $27.8 \%$ for G-AF and G-AFRP respectively. At $600{ }^{\circ} \mathrm{C}$, the improvement in shrinkage was $12.44 \%$ for G-AF and $31.56 \%$ for G-AFRP. The results indicating that, the effect of fibres and particles contribute to much to the control of shrinkage under these formulation conditions. The total linear shrinkage of the geopolymers in the present study was $7.64 \%, 7.17 \%$, and $5.95 \%$ to $940{ }^{\circ} \mathrm{C}$ for $\mathrm{G}, \mathrm{G}-\mathrm{AF}$ and G-AFRP respectively. Other studies have reported overall shrinkage values of approximately $8 \%(69,71)$ for metakaolin based geopolymers heated to $800^{\circ} \mathrm{C}$.

Specific heat, thermal diffusivity and thermal conductivity were evaluated. The measured specific heat (standard deviation of 0.04 ) for geopolymers evaluated in this study is shown in Table 5. All these values are similar to geopolymer materials developed by Jonker et al. (72) using MK and commercial sodium silicate. The specific heat increases slightly with the incorporation of fibres (G-AF and G-CF), however, when RP are added the value specific heat decreases reaching the $G$ matrix value (G-AFRP) or, for G-CFRP being lower. G-AF shows a higher value of specific heat, and a possible cause for the higher heat capacity is that it adsorbs more water from the atmosphere during handling. Thermal diffusivity values for geopolymers are associated with the amount of alkali used and the total alkali content in the crystal phase (73). The diffusivity values obtained for the different geopolymers were between $1.6-2.0 \mathrm{~m}^{2} / \mathrm{s}$ suggesting a low content of free alkali in the structure. The standard deviation of the thermal diffusivity values is in the range of 0 to $5.77 \times 10^{-5} \mathrm{~m}^{2} / \mathrm{s}$. The results obtained show that the thermal conductivity for geopolymers is comparable to materials developed by Prud'homme et al. 
(19) based on MK powders and alkali solutions prepared by mixing the sodium hydroxide solutions with sodium silicate. The values of thermal conductivity for the geopolymers in this study were between $0.15-0.23 \mathrm{~W} / \mathrm{m} \cdot \mathrm{K}$; these values are similar to the values reported by Jonker et al. (72), Prud'homme et al. (19), Duxson et al. (74) and Kamseu (73, 75); which found values of thermal conductivity up to $0.31 \mathrm{~W} / \mathrm{m} \cdot \mathrm{K}$ for geopolymer based on $\mathrm{MK}$ with $\mathrm{Si} / \mathrm{Al}$ ratio of 1.9 using potassium silicate $(71)$ and $\mathrm{Si} / \mathrm{Al}$ ratio of 1.8 using sodium silicate (73). These composites materials developed here have similar thermal conductivity with materials used for insulation application: Portland cement $(0.29 \mathrm{~W} / \mathrm{m} \cdot \mathrm{K})$, insulation plaster gypsum $(0.26-0.30 \mathrm{~W} / \mathrm{m} \cdot \mathrm{K})$, and lightweight concrete $(0.23 \mathrm{~W} / \mathrm{m} \cdot \mathrm{K})(76)$.

The XRD patterns of the samples before and after heat treatment are shown in Figure 6. Sample $\mathrm{G}$ at $25{ }^{\circ} \mathrm{C}$ (Figure 6a) showed a characteristic amorphous hump between $2 \boldsymbol{\theta}$ values $20-35^{\circ}$ as well as a sharper peak attributed to anatase $\left(\mathrm{TiO}_{2}\right.$, Inorganic Crystal Structure Database, ICSD 154604). Anatase was present as an impurity in the original MK and was not dissolved during the activation. After the exposition at $1200{ }^{\circ} \mathrm{C}$, crystalline structures including leucite $\left(\mathrm{KAlSi}_{2} \mathrm{O}_{6}\right.$, Pattern diffraction File, PDF 00-038-1423), kalsilite $\left(\mathrm{KAlSiO}_{4}\right.$, American Mineralogist Crystal Structure Database, AMSCD 1874) and mullite $\left(\mathrm{Al}_{4.8} \mathrm{O}_{9.6} \mathrm{Si}_{1.2}\right.$, PDF 15-776) were observed in both geopolymers with (Figures $6 \mathrm{c}$ and $6 \mathrm{~d}$ ) and without (Figure 6b) reinforcement. The mullite content was notably higher in the G-AFRP composite, which contained refractory particles. The intensity of the leucite peak at $1200{ }^{\circ} \mathrm{C}$ was due to a high content of soluble silicates in the system. These silicates contributed to the formation of a K-A-S-H- rich gel, which crystallized after the heat treatment. The broad hump attributed to the amorphous phases also disappeared after the treatment. Anatase from unreacted MK present after the exposition at 1200 ${ }^{\circ} \mathrm{C}$ was also identified. The G-AF geopolymer exposed to $1200{ }^{\circ} \mathrm{C}$ exhibited a higher intensity of the peaks attributed to kalsilite. Kalsilite is a transition phase structure during leucite hydrothermal crystallization in $\mathrm{Al}, \mathrm{K}$ and $\mathrm{Si}$ systems $(10,77)$. Therefore, higher contents of $\mathrm{Si}$ as well as the presence of $\mathrm{K}$ as an alkali cation, lead to a

TABLE 5. Thermal properties for geopolymer composite at room temperature

\begin{tabular}{lccc}
\hline Sample & Specific Heat (J/kg.K) & Diffusivity $\left(\mathbf{m}^{2} / \mathbf{s}\right)$ & Thermal Conductivity $(\mathbf{W} / \mathbf{m} . \mathbf{K})$ \\
\hline KS & 525.8 & $2.1 \times 10^{-7}$ & 0.2341 \\
G & 936.91 & $1.6 \times 10^{-7}$ & 0.2005 \\
G-AF & 1151.95 & $1.6 \times 10^{-7}$ & 0.2278 \\
G-CF & 838.66 & $1.7 \times 10^{-7}$ & 0.2369 \\
G-AFRP & 894.69 & $2.0 \times 10^{-7}$ & 0.2054 \\
G-CFRP & 692.85 & $1.6 \times 10^{-7}$ & 0.1598 \\
\hline
\end{tabular}

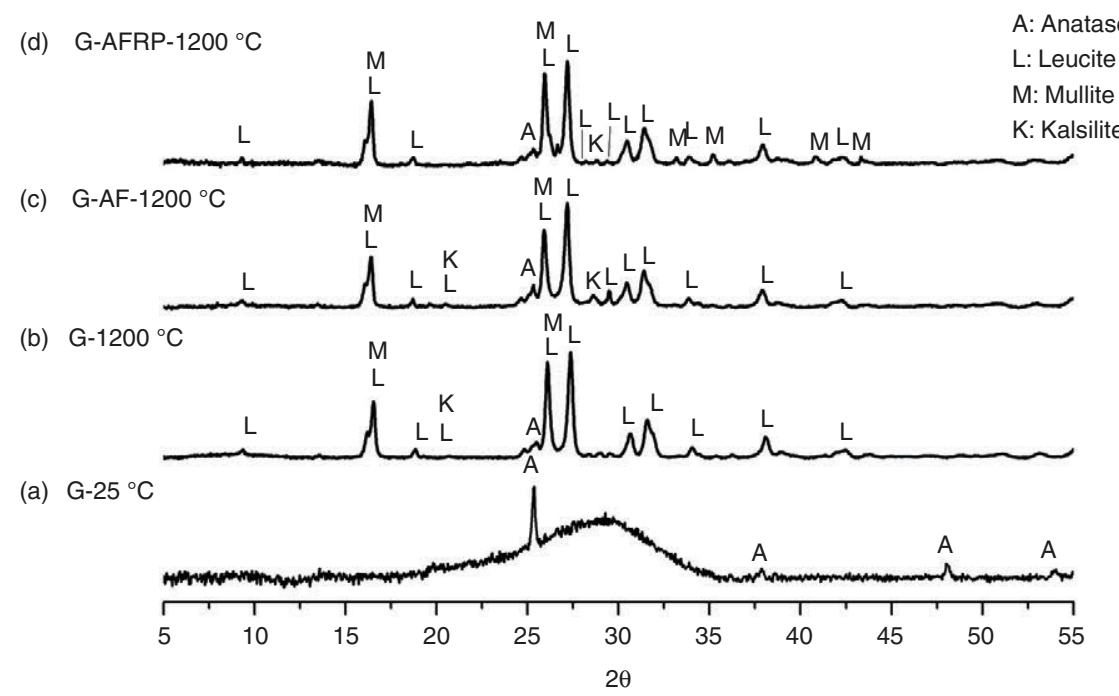

FIGURE 6. XRD patterns for geopolymer composites before and after heat treatment at $1200^{\circ} \mathrm{C}$. 
reduction of activation energy and the promotion of leucite crystallization (77). These results were consistent with studies by Tie - Song et al. (51) and Peipang et al. (58) where the formation of leucite was also promoted by the presence of alkali metals with higher atomic weight and higher contents of $\mathrm{SiO}_{2}(70)$. Sintering and subsequent crystallization of leucite can lead to a significant increase of the mechanical performance, with greater resistance to bending at $100 \mathrm{MPa}$ (54).

SEM was performed on polished geopolymer samples before (Figures 7a and 7b) and after exposure to $1200{ }^{\circ} \mathrm{C}$ (Figures $7 \mathrm{c}$ and $7 \mathrm{~d}$ ). At $25^{\circ} \mathrm{C}$, the morphology of the geopolymer consisted of an amorphous aluminosilicate paste among undissolved or partially dissolved metakaolin sheets. An obvious difference between the images was the degree of porosity. Rickard et al. (67) observed a similar increase in porosity, using SEM images, of fly ash geopolymer exposed to elevated temperatures. The fracture behaviour of investigated composites can be demonstrated clearly with SEM images of fracture surfaces of the composites. The strength of the fibre/ matrix bonds was relatively weak, as shown by the clean surface and holes left behind after the release of fibres. For G-CF, the pulling-out length was short due to the short length of carbon fibres (Figure 7b), causing the fracture work in G-CF to be similar to that for G matrix. For G-AF (Figure 7a), the fracture work was higher because the ceramic fibres were longer. The longer pulling-out length ensured effective toughening and prevented catastrophic fracturing of the composites. After the composites were heat treated at $1200{ }^{\circ} \mathrm{C}$, the fibres were not distinguishable. In the SEM images of sintered samples, shown in Figure 7c and Figure 7d, smooth surfaces with many pores were observed. Two types of pores were observed; channel shaped pores formed by fibre degradation, and spherical pores caused by the evaporation of adsorbed water. The large sizes
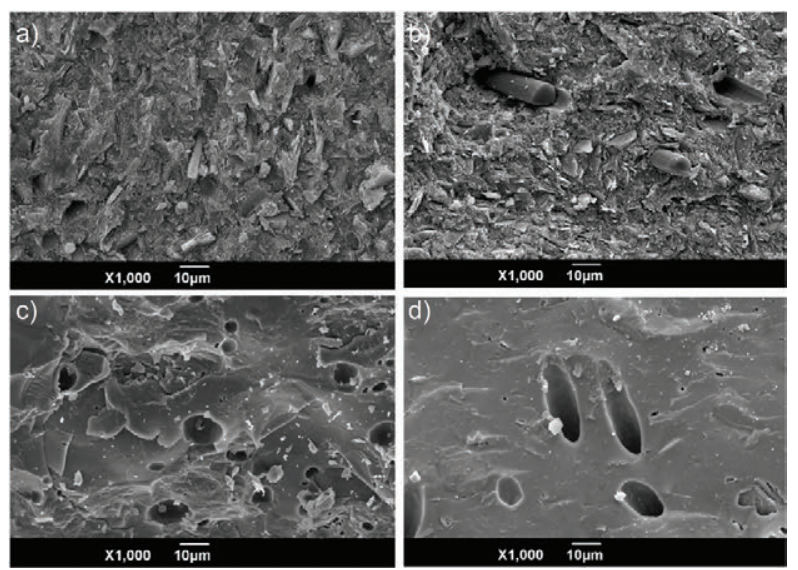

FIGURE 7. SEM images of composite fracture surfaces before (a) G-AF, (b) G-CF, and after (c) G-AF, (d) G-CF heat treatment at $1200{ }^{\circ} \mathrm{C}$ for $2 \mathrm{~h}$. of the spherical pores could be because the samples were not sintered long enough to permit reduction in pore sizes. For G-CF composites, many small oval pores were formed, whereas for G-AF composites, round pores were left after sintering. In both the cases, few cracks were formed due to the shrinkage caused by viscous sintering of geopolymer matrix at high temperature $(9,48)$.

\section{CONCLUSIONS}

Physical properties such as density and porosity and the flexural strength, thermal conductivity in alternative geopolymers produced by RHA-based alkali activator are similar to the geopolymers produced with traditional commercial silicates making the alternative geopolymers a good ecological choice. Aditionally, flexural strength, density, porosity, thermophysical properties and microstructure of MK-based geopolymers activated with RHA and $\mathrm{KOH}$ and reinforced with $\mathrm{CF}, \mathrm{AF}$ and RP have been presented. The high-temperature behaviour of composite geopolymers has also been described. Different types of fibres (carbon and ceramic) and $\mathrm{RP}$ were appropriate reinforcements for room temperature applications. Composites G-CFRP and G-AFRP achieved higher fracture work during flexural testing by (1) the bridging of fibres and (2) particles restraining the movement of geopolymer matrix in their vicinities, essentially receiving some of the applied mechanical stress from the matrix. Furthermore, the ductility of the composite materials was greater than that of the geopolymer matrix. The physical properties and thermal conductivity in the geopolymers composites are similar to the reference sample $\mathrm{G}$. Linear shrinkage for geopolymer composites G-AFRP and G-AF compared with G reference sample is improved by $27.88 \%$ and $7.88 \%$ respectively at $900{ }^{\circ} \mathrm{C}$.

Exposure to high temperatures promoted the structural rearrangement of the geopolymer matrix and densification of interfaces between different components of the composites. G-AFRP and G-CFRP reached peak MOR values of $18.62 \mathrm{MPa}$ and $20.79 \mathrm{MPa}$, respectively. Although the fibres were not stable at high temperature, they prevented cracks, created by thermal stresses generated in the process of elimination of the $\mathrm{OH}$ groups, forming at lower temperatures. The thermal stability and increase in MOR after exposure to high temperatures could be attributed to matrix densification, leucite formation, and proper $\mathrm{RP} /$ matrix interface bond strength. The uses of RHA such a novel silicates source making the geopolymers a good ecological choice. The geopolymer materials developed in this work are porous materials with low thermal conductivity and good mechanical properties with potential thermal insulation applications for building applications. 


\section{ACKNOWLEDGEMENTS}

This study was supported by the Colombian Institute for the Development of Science, Technology, and Innovation (Colciencias) (Project Hybricement, Contract $\mathrm{N}^{\circ}$ 0638-2013), Center of Excellence for Novel Materials - CENM, and Universidad del Valle (Cali, Colombia).

\section{REFERENCES}

1. Torres-carrasco, M.; Palomo, J.G.; Puertas, F. (2014) Sodium silicate solutions from dissolution of glass wastes . Statistical analysis. Mater. Construcc. 64 [314], 1-14. http:// dx.doi.org/10.3989/mc.2014.05213

2. Bajza, A.; Rousekova, I.; Zivica, V. (1998) Silica fumesodium hydroxide binding Systems. Cem. Concr. Res. 28 [1], 13-18. http://dx.doi.org/10.1016/S0008-8846(97) 00192-0

3. Bernal, S.A.; Rodríguez, E.D; Mejía de Gutierrez, R.; Provis, J.; Delvasto, S. (2011) Activation of Metakaolin/ Slag Blends Using Alkaline Solutions Based on Chemically Modified Silica Fume and Rice Husk Ash. Waste and Biomass Valorization. 3 [1], 99-108 http://dx.doi.org/10. 1007/s12649-011-9093-3

4. Detphan, S.;Chindaprasirt, P. (2009) Preparation of fly ash and rice husk ash geopolymer. Int. J. Miner. Metall. Mater. 16 [6], 720-726.

5. Trochez, J.J.; Mejía de Gutiérrez, R.; Rivera, J.; Bernal, S.A. (2015) Synthesis of geopolymer from spent FCC: Effect of $\mathrm{SiO}_{2} / \mathrm{Al}_{2} \mathrm{O}_{3}$ and $\mathrm{Na}_{2} \mathrm{O} / \mathrm{SiO}_{2}$ molar ratios. Mater. Construcc. 65 [317], e046. http://dx.doi.org/10.3989/mc. 2015.00814

6. Robayo, E.; Mejía de Gutiérrez, R.; Gordillo, M. (2016) Natural pozzolan-and granulated blast furnace slag-based binary geopolymers. Mater. Construcc. 66 [321], e077. http://dx.doi.org/10.3989/mc.2016.03615

7. Fawer, M.; Concannon, M.:Rieber, W. (1999) Life cycle inventories for the production of sodium silicates. Int. J. Life Cycle Asses. 4 [4], 201-212. http://dx.doi.org/10.1007/ BF02979498

8. Deabriges, J. (1982) Process for the manufacture of sodium silicate. United States Patent 4336235

9. Villaquirán-Caicedo, M.A.; Mejía de Gutierrez, R.; Sulekar, S.; Davis, C.; Nino, J. (2015) Thermal properties of novel binary geopolymers based on metakaolin and alternative silica sources. Appl. Clay Sci. 118, 276-282. http:// dx.doi.org/10.1016/j.clay.2015.10.005

10. Villaquirán-Caicedo, M.A.; Rodríguez, E.D.; Mejía de Gutierrez, R. (2015) Evaluacion microestructural de geopolimeros basados en metacaolin y fuentes alternativas de silice expuestos a temperaturas altas. Ing. Investig. y Tecnol. 16 [1], 113-122, ISSN 1405-7743.

11. Villaquirán-Caicedo M.A.; Mejía de Gutierrez, R. (2015) Synthesis of ternary geopolymers based on metakaolin , boiler slag and rice husk ash, DYNA, 82 [194], 104-110. http://dx.doi.org/10.15446/dyna.v82n194.46352.

12. Nazari A.; Rohani, A.F. (2012) Alkali-activated geopolymer produced by seeded fly ash and rice husk bark ash. Adv. Cem. Res. 24 [5], 301-309. http://dx.doi.org/10.1680/ adcr. 11.000 .38

13. Mejía, J.M.; Mejía de Gutierrez, R.;Montes, C. (2016) Rice husk ash and spent diatomaceous earth as a source of silica to fabricate a geopolymeric binary binder. J. Clean. Prod. 118, 133-139. http://dx.doi.org/10.1016/j.jclepro. 2016.01.057

14. Haeng Heo, U.; Sankar, K.; Kriven, W.M.; Musil, S.S. (2014) Rice Husk Ash as a Silica Source in a Geopolymer Formulation," in Developments in Strategic Materials and Computational Design V: A Collection of Papers Presented at the 38th International Conference on Advanced Ceramics and Composites. http://dx.doi.org/10. 1002/9781119040293.ch7
15. Fongang, R.T.; Pemndje, J.; Lemougna, P.N.; Melo, U.C.; Nanseu, C.P.; Nait-Ali, B.; Kamseu, E. and Leonelli, C. (2015) Cleaner production of the lightweight insulating composites: Microstructure, pore network and thermal conductivity," Energy Build. 107, 113-122. http://dx.doi. org/10.1016/j.enbuild.2015.08.009

16. Bouzón, N.; Payá, J.; Borrachero M.V.; Soriano, L.; Tashima, M.M. and Monzó, J. (2014) Refluxed rice husk ash/ $\mathrm{NaOH}$ suspension for preparing alkali activated binders, Mater. Lett. 115, 72-74. http://dx.doi.org/10.1016/j. matlet.2013.10.001

17. Mejía, J.M.; Mejía de Gutierrez, R.; Puertas, F. (2013) Rice husk ash as a source of silica in alkali-activated fly ash and granulated blast furnace slag systems. Mater. Constr. 63 [311], 361-375. http://dx.doi.org/10.3989/mc.2013.04712

18. Zivica, V. (2006) Effectiveness of new silica fume alkali activator. Cem. Concr. Compos. 28 [1], 21-25. http://dx.doi. org/10.1016/j.cemconcomp.2005.07.004

19. Prud'homme, E.; Michaud, P.; Joussein, E.; Peyratou, C.; Smith, A.; Arrii-Clacens S.; Clacens, J.M.; Rossignol, S. (2010) Silica fume as porogent agent in geo-materials at low temperature. J. Eur. Ceram. Soc. 30 [7], 1641-1648. http:// dx.doi.org/10.1016/j.jeurceramsoc.2010.01.014

20. Prud'homme, E.; Michaud, P.; Joussein, E.; Peyratou, C.; Smith, A.; Rossignol, S. (2011) In situ inorganic foams prepared from various clays at low temperature. Appl. Clay Sci. 51 [1-2], 15-22. http://dx.doi.org/10.1016/j.clay.2010.10.016

21. Bernal, S.A.; Rodríguez, E.D.; Mejía de Gutiérrez, R.; Provis, J.L. (2015) Performance at high temperature of alkali-activated slag pastes produced with silica fume and rice husk ash based activators. Mater. Construcc. 65 [318], e049. http://dx.doi.org/10.3989/mc.2015.03114

22. Torres-Carrasco M.; Puertas, F. (2015) Waste glass in the geopolymer preparation. Mechanical and microstructural characterisation. J. Clean. Prod., 90, 397-408. http://dx.doi. org/10.1016/j.jclepro.2014.11.074

23. Torres-Carrasco, M.; Rodríguez-Puertas, C.; Alonso, M.; Puertas, F. (2015) Alkali activated slag cements using waste glass as alternative activators. Rheological behaviour. Boletín la Soc. Española Cerámica y Vidr. 54 [2], 45-57. http://dx.doi.org/10.1016/j.bsecv.2015.03.004

24. Badanoiu, A.I.; Al Saadi, T.H.; Stoleriu, S.; Voicu, G. (2015) Preparation and characterization of foamed geopolymers from waste glass and red mud. Constr. Build. Mater. 84, 284-293. http://dx.doi.org/10.1016/j.conbuildmat. 2015.03 .004

25. Tchakouté, H.K.; Crüscher, C.H.; Kong, S; Kamseu, E.; Leonelli, C. (2016) Geopolymer binders from metakaolin using sodium waterglass from waste glass and rice husk ash as alternative activators: A comparative study. Constr. Build. Mater. 114, 276-289. http://dx.doi.org/10.1016/j. conbuildmat.2016.03.184

26. Autef, A.; Joussein, E.; Gasgnier, G.;Rossignol, S. (2012) Role of the silica source on the geopolymerization rate. J. Non. Cryst. Solids. 358 [21], 2886-2893. http://dx.doi. org/10.1016/j.jnoncrysol.2012.07.015

27. Tawfik, A.F.; El-raoof, A.; Katsuki, H.; Mackenzie, K.J. D.; Komarneni, S. (2016) K-Based Geopolymer from metakaolin : roles of $\mathrm{K} / \mathrm{Al}$ ratio and water or steam Curing at different temperatures. Mater. Construcc. 66 [322], e081. http://dx.doi.org/10.3989/mc.2016.03115

28. Ahmed, Y.M.; Ewais, E.;Zaki,Z.(2008) Production of porous silica by the combustion of rice husk ash for tundish lining. J. Univ. Sci. Technol. Beijing, Miner. Metall. Mater. 15 [3], 307-313. http://dx.doi.org/10.1016/S1005-8850(08)60058-4

29. Sun, L.; Gong, K. (2001) Silicon-Based Materials from Rice Husks and Their Applications. Ind. Eng. Chem. Res. 40 [25], 5861-5877. http://dx.doi.org/10.1021/ie010284b

30. Krishnarao, R.; Subrahmanyam, J.; Jagadish Kumar, T. (2001) Studies on the formation of black particles in rice husk silica ash. J. Eur. Ceram. Soc. 21 [1] 99-104. http:// dx.doi.org/10.1016/S0955-2219(00)00170-9

31. Hwang C.L.; Huynh, T.P. (2015) Investigation into the use of unground rice husk ash to produce eco-friendly construction bricks. Constr. Build. Mater. 93, 335-341. http:// dx.doi.org/10.1016/j.conbuildmat.2015.04.061 
32. FAO (2013) Rice Market Monitor, Food Agric. Organ. United Nations. 16 (4), 1-38.

33. USA Rice Federation. 201. Facts. [Online]. Available: http://www.usarice.com/

34. DANE. (2015) Boletín Técnico. Available: http://www.dane. gov.co/files/investigaciones/boletines/arroz/bol_arroz Isem15.pdf?phpMyAdmin=a9ticq8rv198vhk5e8cck52r11

35. Wang, H.; Li, H.; Yan, F. (2005) Reduction in wear of metakaolinite-based geopolymer composite through filling of PTFE. Wear. 258 [10], 1562-1566. https://dx.doi. org/10.1016/j.wear.2004.11.001

36. Puertas, F.; Amat, T.; Vázquez, T. (2000) Comportamiento de morteros de cementos alcalinos reforzados con fibras acrílicas y de polipropileno. Mater. construcc. 50 [259], 69-84. http://dx.doi.org/10.3989/mc.2000.v50.i259.400

37. Ranjbar, N.; Talebian, S.; Mehrali, M.; Kuenzel, C.; Simon, H.; Metselaar, C. and Zamin, M. (2016) Mechanisms of interfacial bond in steel and polypropylene fiber reinforced geopolymer composites. Compos. Sci. Technol. 122, 73-81. http://dx.doi.org/10.1016/j. compscitech.2015.11.009

38. Yunsheng, Z.; Wei, S.; Zongjin, L.; Xiangming, Z.; Chungkong, C. (2008) Impact properties of geopolymer based extrudates incorporated with fly ash and PVA short fiber. Constr. Build. Mater. 22 [3] pp. 370-383. http://dx.doi. org/10.1016/j.conbuildmat.2006.08.006

39. Musil, S.; Kutyla, G.; Kriven, W.M. (2013) The effect of basalt chopped fiber reinforcement on the mechanical properties of potassium based geopolymer. Ceram. Eng. Sci. Proceed. 33 [10], 31-42. http://dx.doi.org/10.1002/ 9781118217542.ch4

40. Dias D.P.;Thaumaturgo, C. (2005) Fracture toughness of geopolymeric concretes reinforced with basalt fibers. Cem. Concr. Compos. 27 [1], 49-54. http://dx.doi.org/10.1016/j. cemconcomp.2004.02.044

41. Giancaspro, J.; Papakonstantinou, C.G.;Balaguru, P.N. (2010) Flexural Response of Inorganic Hybrid Composites With E-Glass and Carbon Fibers. J. Eng. Mater. Technol. 132 [2], 021005. http://dx.doi.org/10.1115/1.4000670

42. Puertas F. ; Gil-Maroto, A. (2006) Alkali-activated slag mortars reinforced with ar glassfibre: Performance and properties. Mater. Constr. 56 [283], 79-90. http://dx.doi.org/10.3989/ mc.2006.v56.i283.10

43. Lin, T.; Jia, D.; Wang, M.; He, P.G.; Liang, D. (2009) Effects of fibre content on mechanical properties and fracture behaviour of short carbon fibre reinforced geopolymer matrix composites. Bull. Mater. Sci. 32 [1], 77-81. http:// dx.doi.org/10.1007/s12034-009-0011-2

44. Alcaide, J.S.; Alcocel, E.G. (2007) Carbon fibre-reinforced, alkali-activated slag mortars. Mater. Constr. 57 [288], 33-48. http://dx.doi.org/10.3989/mc.2007.v57.i288.63

45. Bernal, S.; Bejarano, J.; Garzón, C.; Mejía de Gutierrez, R.; Delvasto, S.; Rodríguez, E. (2012) Performance of refractory aluminosilicate particle/fiber-reinforced geopolymer composites. Compos. Part B Eng. 43 [4], 1919-1928. http:// dx.doi.org/10.1016/j.compositesb.2012.02.027

46. Silva F.J.;Thaumaturgo, C. (2003) Fibre reinforcement and fracture response in geopolymeric mortars. Fatigue Fract. Eng. Mater. Struct. 26 [2], 167-172. http://dx.doi. org/10.1046/j.1460-2695.2003.00625.x

47. Bernal, S.; Mejía de Gutierrez, R.; Delvasto, S.; Rodríguez, E. (2010) Performance of an alkali-activated slag concrete reinforced with steel fibers. Constr. Build. Mater. 24 [2], 208214 http//dx doi org/10 1016/j.conbuildmat 2007.10.027

48. He, P.; Jia, D.; Lin, T.; Wang, M.; Zhao, Y. (2010) Effects of high-temperature heat treatment on the mechanical properties of unidirectional carbon fiber reinforced geopolymer composites. Ceram. Int. 36 [4], 1447-1453. http://dx.doi. org/10.1016/j.ceramint.2010.02.012

49. Kamseu, E.; Rizzuti, A.; Leonelli, C.; Perera, D. (2010) Enhanced thermal stability in $\mathrm{K}_{2} \mathrm{O}$-metakaolin-based geopolymer concretes by $\mathrm{Al}_{2} \mathrm{O}_{3}$ and $\mathrm{SiO}_{2}$ fillers addition. $J$. Mater. Sci. 45 [7], 1715-1724. https://dx.doi.org/10.1007/ s10853-009-4108-1

50. Phair, J.W.; Van Deventer, J.; Smith, J.D. (2000) Mechanism of Polysialation in the Incorporation of Zirconia into Fly
Ash-Based Geopolymers. Ind. Eng. Chem. Res. 39 [8], 29252934. http://dx.doi.org/10.1021/ie990929w

51. Tie-song, L.; De-chang, J.; Pei-gang, H.; Mei-rong, W. (2009) Thermal-mechanical properties of short carbon fiber reinforced geopolymer matrix composites subjected to thermal load. J. Cent. South Univ. Technol. 16 [6], 881-886. https://dx.doi.org/10.1007/s11771-009-0146-8

52. Kuenzel, C.; Li, L.; Vandeperre, L.; Boccaccini, A.; Cheeseman, C. (2014) Influence of sand on the mechanical properties of metakaolin geopolymers. Constr. Build. Mater. 66, 442-446. http://dx.doi.org/10.1016/j.conbuildmat. 2014.05.058

53. Duxson, P.; Lukey, G.C. and Deventer, J. (2007) Physical evolution of Na-geopolymer derived from metakaolin up to $1000^{\circ} \mathrm{C}$. J. Mater. Sci. 42 [9], 3044-3054. http://dx.doi. org/10.1007/s10853-006-0535-4

54. He, P.; Yang, Z.; Yang, J.; Duan, X.; Jia, D.; Wang, S.; Zhao, Y.; Wang, Y.; Zhang, P. (2015) Preparation of fully stabilized cubic-leucite composite through heat-treating Cs-substituted K-geopolymer composite at high temperatures. Compos. Sci. Technol. 107, 44-53. http://dx.doi. org/10.1016/j.compscitech.2014.11.009

55. American Society for Testing \& Materials. (2013) C1341 Standard Test Method for Flexural Properties of Continuous Fiber-Reinforced Advanced Ceramic Composites.

56. Parker, W.; Jenkins, R.; Butler, C.; Abbott, J. (1961) A Flash Method of Determining thermal Diffusivity, Heat Capacity, and Thermal Conductivity. Appl. Phys. 32, 714-719. http://dx.doi.org/10.1063/1.1728417

57. Zhang, M.H.; Lastra, R.; Malhotra, V. (1996) Rice Husk Ash Paste and Concrete: some aspects of hydration and the microstructure of the interfacial zone between the aggregate and paste. Cem. Concr. Res. 26 [6], 963-977. http:// dx.doi.org/10.1016/0008-8846(96)00061-0

58. He, P.G.; Jia, D.; Wang, M.; Zhao, Y. (2010) Effect of cesium substitution on the thermal evolution and ceramics formation of potassium-based geopolymer. Ceram Int. 36 [8], 2395-2400. http://dx.doi.org/10.1016/j.ceramint. 2010.07.015

59. Masi, G.; Rickard W.; Bignozzi M.; Van Riessen, A. (2015) The effect of organic and inorganic fibres on the mechanical and thermal properties of aluminate activated geopolymers. Compos. Part B Eng. 76, 218-228. http://dx.doi. org/10.1016/j.compositesb.2015.02.023

60. Zhang, H.Y.; Kodur, V.; Cao, L.; Qi, S. (2014) Fiber Reinforced Geopolymers for Fire Resistance Applications. Procedia Eng. 71, 153-158. http://dx.doi.org/10.1016/j.proeng.2014.04.022

61. Karim, M.R.; Zain, M.F.; Jamil, M.; Lai, F.C. (2013) Fabrication of a non-cement binder using slag, palm oil fuel ash and rice husk ash with sodium hydroxide. Constr. Build. Mater. 49, 894-902. http://dx.doi.org/10.1016/j. conbuildmat.2013.08.077

62. Luna-Galiano, Y.; Cornejo, A.; Leiva, C.; Vilches, L.; Fernández-Pereira, C. (2015) Properties of fly ash and metakaolín based geopolymer panels under fire resistance tests. Mater. Construcc. 65 [319], e059. http://dx.doi. org/10.3989/mc.2015.06114

63. Lyon, R.; Balaguru, P.; Foden, A. (1997) Fire-resistant aluminosilicate composites. Fire Mater. 21, 67-73

64. Martauz, P.; Janotka, I.; Strigác, J.; Bacauvcík, M. (2016) Fundamental properties of industrial hybrid cement : utilization in ready-mixed concretes and shrinkage-reducing applications. Mater. Construcc. 66 [322], e084. http://dx.doi. org $/ 10.3989 / \mathrm{mc} .2016 .04615$

65. Latella, B.A.; Perera, D.; Durce, D.; Mehrtens, E.G. and Davis, J. (2008) Mechanical properties of metakaolin-based geopolymers with molar ratios of $\mathrm{Si} / \mathrm{Al} \approx 2$ and $\mathrm{Na} / \mathrm{Al} \approx 1$," J. Mater. Sci. 43 [8], 2693-2699. http://dx.doi.org/10.1007/ s10853-007-2412-1

66. Zuda, L.; Drchalová J.; Rovnaník, P.; Bayer, P.; Keršner, Z.; Černý, R. (2010) Alkali-activated aluminosilicate composite with heat-resistant lightweight aggregates exposed to high temperatures: Mechanical and water transport properties. Cem. Concr. Compos. 32 [2], 157-163. http://dx.doi. org/10.1016/j.cemconcomp.2009.11.009 
67. Rickard, W.D.; Van Riessen, A.; Walls, P. (2010) Thermal Character of Geopolymers Synthesized from Class F Fly Ash Containing High Concentrations of Iron and a-Quartz. Int. J. Appl. Ceram. Technol. 7 [1], 81-88. http:// dx.doi.org/10.1111/j.1744-7402.2008.02328.x

68. Van Riessen A.; Rickard W.D.; Sanyan, J. (2009) Thermal properties of geopolymers, Geopolymers: Structures, Processing, Properties and Industrial Applications. ed Provis, J.L and Van Deventer, J.S.J., 315-342. Cmabridge, UK: Woodhead Publishing Limited.

69. Barbosa V.F. and MacKenzie, K.J. (2003) Synthesis and thermal behaviour of potassium sialate geopolymers. Mater. Lett. 57 [9-10], 1477-1482. http://dx.doi. org/10.1016/S0167-577X(02)01009-1

70. Bell, J.L.; Driemeyer, P.E.; Kriven, W.M. (2009) Formation of Ceramics from Metakaolin-Based Geopolymers. Part II: K-Based Geopolymer. J. Am. Ceram. Soc. 92 [3], 607-615. http://dx.doi.org/10.1111/j.1551-2916.2008. 02922.x

71. Duxson, P.; Lukey, G.C.; Van Deventer, J.S.J. (2006) Thermal evolution of metakaolin geopolymers: Part 1 - Physical evolution. J. Non. Cryst. Solids. 352 [52-54], 5541-5555. http:// dx.doi.org/10.1016/j.jnoncrysol.2006.09.019

72. Jonker, A.; McCrindle, R.I.; Van der Merwe, M. (2009) Insulating Refractory Materials from Inorganic waste
Sources. The Refractories Engineer. 14-19. Available in http://www.irengineers.co.uk

73. Kamseu, E.B.; Ceron, H.; Tobias, E.; Leonelli, M.C.; Bignozzi, A.; Muscio, A.; Libbra, A. (2011) Insulating behavior of metakaolin-based geopolymer materials assess with heat flux meter and laser flash techniques. J. Therm. Anal. Calorim. 108 [3], 1189-1199. http://dx.doi.org/10.1007/s10973-011-1798-9

74. Duxson, P.; Lukey, G.C. and Van Deventer, J.S.J. (2006) Evolution of gel structure during thermal processing of Na-geopolymer gels. Langmuir. 22 [21], 8750-8757, Oct. http://dx.doi.org/10.1021/la0604026

75. Kamseu, E.; Nait-Ali, B.; Bignozzi, M.C.; Leonelli, C.; Rossignol, S. and Smith, D.S. (2012) Bulk composition and microstructure dependence of effective thermal conductivity of porous inorganic polymer cements. J. Eur. Ceram. Soc. 32 [8], 1593-1603. http://dx.doi.org/10.1016/j. jeurceramsoc.2011.12.030

76. CTE, Catálogo de elementos constructivos. Código técnico de la edificación. Madrid, ESPANA, 2010. Avalaible in http://www.codigotecnico.org/images/stories/pdf/aplicaciones/nCatalog_infoEConstr/CAT-EC-v06.3_marzo_10.pdf

77. Zhang, Y.; Lv, M.; Chen, D. and Wu, J. (2007) Leucite crystallization kinetics with kalsilite as a transition phase," Mater. Lett. 61 [14-15], 2978-2981. http://dx.doi.org/10.1016/j. matlet.2006.10.057 